\title{
Burial Crypts and Vaults in Britain and Ireland: a Biographical Approach
}

Various types of burial chamber in Britain belonging to the period from the Reformation until the $19^{\text {th }}$ century have long been investigated archaeologically, but their frequency was only appreciated with the extensive investigation of St. Augustine the Less, Bristol, for which unfortunately there is still only an interim report (Boore 1986). The initial classification of both coffins and burial spaces was produced by Julian Litten (1985), and the variability in coffin design was greatly expanded by the investigation of the communal crypt at Christ Church Spitalfields, London (hereafter Spitalfields) during 1984-1986 (Reeve, Adams 1993). The original classification and dating sequence for burial structures proposed by Litten (1985: IO) is still valid, and it is set out in Table I. Mainly concentrating on elite burial spaces, Litten defined four categories of burial space in 1999: large dynastic vault, family vault, brick grave and extensive private and public vaults (Litten 1999: II5). This study defines the range of types that are most frequently encountered and the form of the evidence normally surviving in these burial spaces, building on these pioneering studies.

This study considers for the first time the biography of the coffin, and of the various types of burial spaces, both in terms of successive interment and some of the subsequent taphonomic processes that subsequently affect the location of the coffins within these burial spaces. The categories of space are organised by size, starting with the smallest, for one or two individuals, through family vaults of varying size to communal crypts. Given the paucity of dating evidence for construction of many vaults, and the relatively small sample that is available through academic publication and the 'grey literature' of contract archaeology, no detailed chronology or appreciation of regional variation can yet be confidently proposed. Whilst the dates obtained from coffins, with their depositum plates providing details of the deceased, can suggest a date for a burial space, they are not always 
reliable. Coffins could be moved from one grave to a new family burial space to keep family members together in death. Nevertheless, it seems that elite vaults were constructed from the later $15^{\text {th }}$ century onwards, with middle class vaults and lined burial shafts commencing during the $17^{\text {th }}$ century and increasing in popularity in later centuries. Church crypts become popular in major towns and cities from the later $18^{\text {th }}$ century but their use ended with legislation against all intra-mural burial in the middle of the $19^{\text {th }}$ century. Family vaults continue in use, but they are rarely constructed today.

Numerous crypts and family burial vaults, particularly those thought to contain royal or aristocratic individuals, were frequently opened and explored during $19^{\text {th }}$-century renovations of church buildings. For example, a search in Westminster Abbey for the remains of James I led to the examination of some of the earliest known vaults, such as that for Mary, Queen of Scots (died 1587). Several early $17^{\text {th }}$-century vaults, some with anthropoid coffins, were revealed there, and similar vaults elsewhere were also erected at this time (Litten 2009; Stanley 1869). Elite family vaults have been investigated in recent times (Litten 1999; Redknap 1985; Butler, Morris 1994). These, together with brief descriptions in local sources, and his other unpublished observations provided Litten with the evidence for the original classification and his update. More recent extensive investigations and numerous small-scale observations have shown that these categories, whilst largely correct, do not reflect the full richness of both the original designs and the ways in which such spaces were adapted and filled. This chapter is the first attempt to explore and understand this complexity, building on Litten's pioneering work biased on a wider range of examples.

In the first two decades of the $2 \mathrm{I}^{\text {st }}$ century numerous subterranean burial structures have been recorded, though they were often unexpectedly discovered by accident during church refurbishment and observed or rapidly recorded as part of the archaeological oversight of such projects. The unexpected appearance of such features, and the limited experience of dealing with such opportunities by many of the contractors, has led to inconsistent recording procedures and terminology. Nevertheless, some information from a wide range of locations augments the largescale investigations at a small number of graveyards and internal vaults and crypts where more intensive investigation has taken place. Although the St. Martins-inthe-Bull Ring, Birmingham (hereafter St. Martins; Brickley, Buteux 2006), was a significant investigation away from the capital, but most of the major studies have been in London, notably at the subject-defining site of Spitalfields (Reeve, Adams 1993), followed by St. George's Church, Bloomsbury (hereafter Bloomsbury; Boyle et al. 2005) and St. Luke's, Islington (hereafter St. Luke'; Boston et al. 2009). The present data set is already sufficient to confirm the main forms of burial vault found across Britain and Ireland and also consider some of the variation in their 
details; it forms part of a wider burgeoning archaeological interest in post-medieval mortuary culture in Britain and Ireland (Cherryson et al. 20I2; Renshaw, Powers 2016; Mytum 2017; 2018a). Whilst individual narratives have been elucidated in site reports, it is now possible to compare and contrast the varied biographies of both coffins and their burial chambers across a range of sites for the first time.

\section{Biographies of shafts, vaults and crypts}

\section{Brick or stone burial shafts}

Shafts designed to contain one or more coffins stacked above each other were the simplest form of construction beyond the earth-dug grave. They mirror in size and organisation the simple grave, but are lined with brick or, on some regions, stone. They provided the least expensive form of protection of the interred from disturbance from later burials. These shafts occur within churches, but also in churchyards and burial grounds of different denominations (Cox, Stock 1996).

Shafts could be rectangular or hexagonal in shape, and if lined with brick could be one or two bricks thick. The 24 examples investigated at St. Martins show the common forms found elsewhere (Brickley, Buteux 2006: 70-89), and most were closed with a barrel vault, though some were covered with a ledger slab. The vault would have to be dismantled for each interment, but in some cases an area was excavated at the end of the grave to enable the narrow east or west end wall to be dismantled and the next coffin to be inserted. It was easier to move aside a ledger for subsequent burials, as these could be lowered down from above. Some shafts were enhanced on the inner faces with whitewash. A memorial - floor slab inside the church or ledger or another form of monument in the churchyard - would mark the position of the shaft and give details of those interred beneath. Shafts were designed for two adult interments, but some of those at St. Martins also contained up to two additional infants or children.

The use of the shafts was similar in all cases, with coffins placed one above another, though not normally actually resting on each other, though how this was achieved does vary. The first coffin was placed in the base, but subsequent interments were rested above this with two timbers placed across the width of the shaft, either in already prepared putlog holes, or ones that were cut out as required. Alternatively, the iron bars were set between the courses of brick or masonry. At St. Martin's, the lower burial was occasionally sealed with a full floor over it (Brickley, Buteux 2006: 72). In the majority of shafts with transverse supports, the next coffin could be lowered down and rested on these, ensuring that the first coffin was not crushed. Some of the shafts at St. Luke's did not have the supports and the coffins were just stacked one on top of another (Boyle et al. 
2005: 57). In most shafts, as the coffins decayed, the surviving fragments and the coffin fittings and contents fell to the bottom. This can mean that establishing the original sequence and appearance of the coffins can be difficult.

\section{Small family vaults}

Small family vaults were usually constructed as small rectangular chambers with brick walls and arched roof. These allow two burials side by side, rather than one above the other, as with the shafts, usually directly on the floor but sometimes on timbers to allow air to circulate (Mytum 1988). Other family vaults incorporated the coffin stacking concept of the shafts with transverse supports to allow up to four levels. Small family vaults occur both within churches and in graveyards, often under horizontal ledger stones or tombs. An example of a vault beneath a chest tomb is that rapidly recorded at Aldersgate Street, London (Wroe-Brown 20II), and others were identified at St. Luke's and St. Martins-in-the-Bull Ring. The Aldersgate Street vault, designed to take two coffins side by side, had an entrance at the eastern end of the grave, allowing coffins to be moved down to sit the length of the grave space beneath the tomb, though other small vaults, such as those at St. Luke's, generally had an access point on one of the longer sides. Internal vaults usually had steps, but external ones often required dug to be dug away to provide access from an end or side. In these cases, other burials had to placed away from the area that would be disturbed to access the vault, and so affected wider burial ground management.

In the churchyard of All Saints' Church, Bisley, Gloucestershire, an external stone-built burial chamber c. $2.2 \mathrm{~m} \mathrm{x} 2.1 \mathrm{~m} \times 2.1 \mathrm{~m}$ beneath a pair of ledger stones for William Tyloe (died I8०8) and his wife Mary (died I8I8) was inspected during conservation work. The human remains and coffin fittings were well preserved but disturbed, in part from the decay of the coffins but also possibly by a fluctuating water table and animal disturbance (Williams 2007). An alternative is that the coffins may have been raised above the base of the chamber on wooden beams that were set in putlog holes in the walls, and they would have become scattered once the wooden coffins decayed. Natural taphonomic processes have been little studied in terms of vault biography to date. An unusual feature of this vault was that access was gained by way of a coffin-slide tunnel with an aperture of c. 1.2 $\mathrm{m} \times 0.8 \mathrm{~m}$ and near the surface; this allowed coffins to be placed into the space without removing the ledgers over the top, or digging a large amount of earth away to allow a wall to be dismantled.

The vaults at St. Martins reveal a variety of external forms, some only a single level, others with several levels up to four. Most single level vaults were separate structures as with the Bisley example already discussed, but some were grouped together with separate rooms all accessed from a single subterranean corridor with 
one shared set of steps for access. This multiple vault structure was a speculative development by the church, constructed c. 1785 , and each space was sold to an individual family, with its entrance bricked up between interments. These vaults were similar to those built within communal crypts such as St. Luke's discussed below. The four chambers varied in their intensity of use between a single adult in Chamber A to five adults in two stacks and three children in another stack within Chamber D.

The multiple level vaults at St. Martins had their layers of coffins separated by using transverse timbers in the same arrangement as with the grave shafts discussed above. The Ainsworth vault (Fig. I) was first used for two children's interments ( $\mathrm{I}, 2)$ in one corner, with the other two adults later occupying most of the space, all dying within the space of a decade (Brickley, Buteux 2006: 39-42). Level 2 contains just two adults, again interred a decade apart, and the third level was filled with coffins for three adults. Most of the coffins in this vault can be dated, and they reveal that a straightforward stratigraphic sequence starting from the bottom was not always the case, as the middle level contains Elizabeth Ainsworth and her husband, John, who died after his brother Benjamin who was placed on the highest level to leave room for John to join his wife.

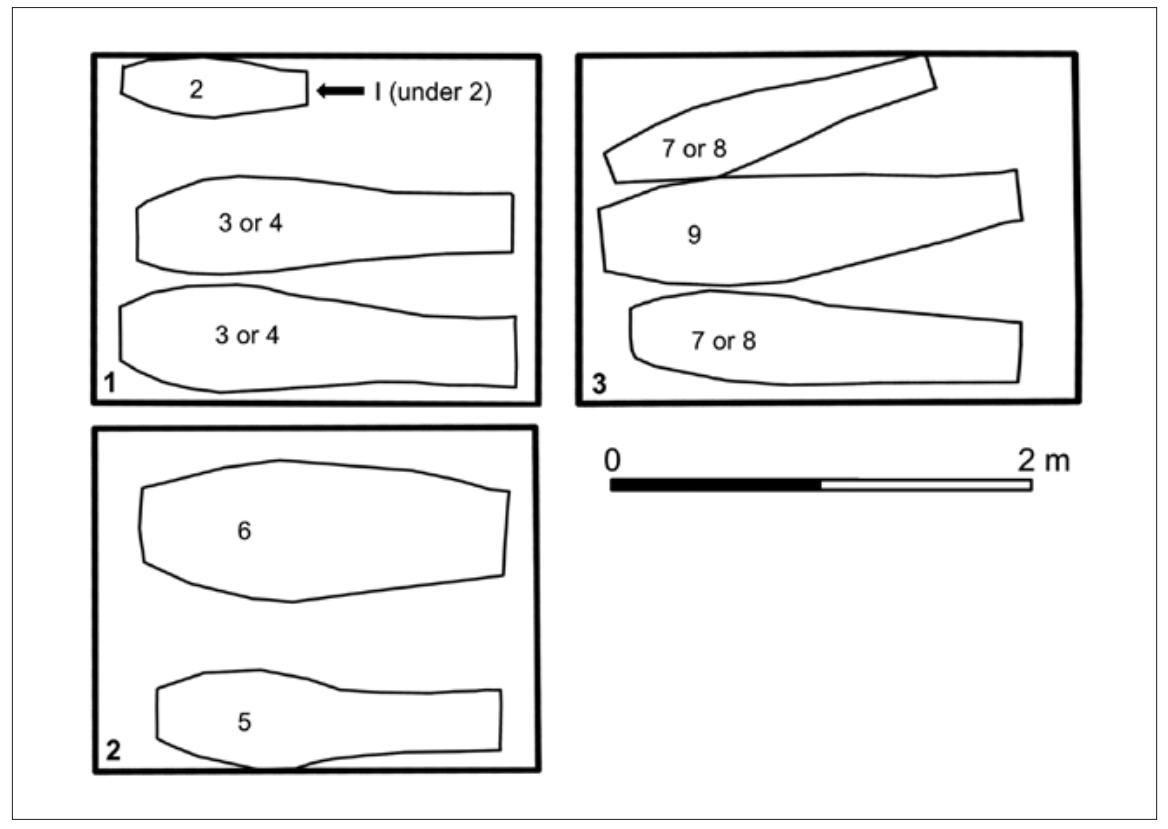

Fig. 1. Plans of the three levels in the Ainsworth vault, St. Martins-in-the-Bull Ring, Birmingham. The lowest is level 1, followed by level 2 with level 3 the highest (Mytum and Philpott, simplified from Brickley, Buteux 2006). 
This indicates that the transverse timbers for the upper two layers of coffins were built into the structure from the start. These vaults were not opened from the top, as was the case with the shafts, but from a side or end, so coffins could be slid into any layer within the vault.

An interior vault was investigated at Boone's Chapel, Lewisham (Langthorne 2006). Measuring c. I.6 by $2.4 \mathrm{~m}$ and $1.5 \mathrm{~m}$ high, this brick-lined barrel-vaulted structure was constructed in the Boone chapel for the family of that name in 1686. The interior was only viewed through a gap in the wall and two coffins for adults could be identified. One was collapsed but a breastplate for Christopher Boone could be seen. The other more complete example retained a coffin stud design pattern of two parallel rows which would have held a fabric covering in place. This is likely to be Christopher's wife Mary who died in 1722 . No other interments would appear to have been added as these would have been on top of the two original occupants.

Some vaults of this scale were used over longer periods of time. A vault at Cuddington, Buckinghamshire, measured $2.5 \times 2.6 \times 2.2 \mathrm{~m}$ and contained five coffins when observed during the installation of a new floor on the north aisle; two could be dated and belonged to the Clarke family, with Dorothy dying in 1752 aged 22 and Rupert in I8II aged 76 years (Lewis 2009), 59 years apart; the pattern of vault use at the two sites with the largest samples - St. Luke's and St. Martins - is discussed below as an aspect of vault biography.

Vaults could be reused during building alterations. Vault 106 in the chapel of St.John's College, Oxford had its roof removed when heating ducts were installed in the Victorian period, and this was replaced with a covering slab (Dean, Hiller 2008: 4). As the vault interior contained a large amount of disarticulated human remains, it is likely that this was formed of human remains recovered during the construction of the duct and placed in this convenient space before it was re-sealed. As the vault was not excavated, it is not known whether the original occupants lie undisturbed beneath the charnel. Many sites have produced evidence of internal family vaults being subsequently used as a convenient location for charnel.

In Ireland, small family vaults were often constructed of stone, though others were in brick. Many have barrel vault roofs close to the surface, but others are partly above-ground structures. In these latter cases the entrances could be closed off with iron doors or grilles or infilled with brick or stone, sometimes then plastered over. Examples from Donaghmoyne, County Monaghan, demonstrate the structure, and a missing stone in the end wall allowed observation of the interior with its extremely disturbed contents, suggesting animal and possibly human entry in the past (Fig. 2). Many other forms of vault, often in regional styles such as those found in County Kerry (Mytum 2012: 9), can only be observed externally and so are not further discussed here. 

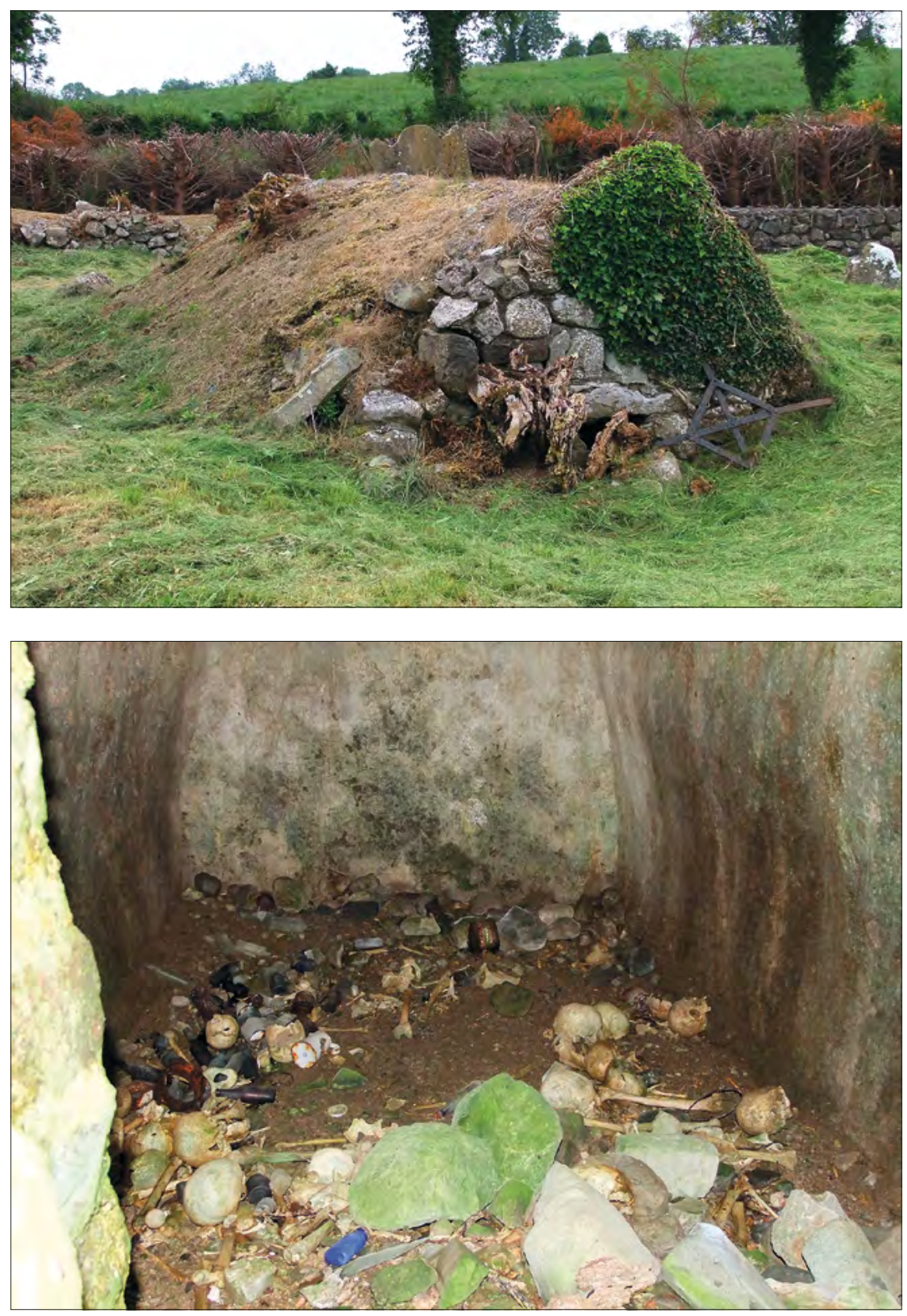

Fig. 2. External partially subterranean burial vaults, Donaghmoyne, County Monaghan. Top: Outside view of family vault. Bottom: Interior view of family vault (photographs by H. Mytum). 
Large family vaults

Aristocratic families often constructed vaults within churches during the $17^{\text {th }}$ century, sometimes beneath the floors of chapels that had been built as chantry chapels for their ancestors before the Reformation. Although prayers for the soul of the deceased were no longer such a priority, the coherence of family remained, so the burial vaults in use continued much as before. The funeral customs changed (Litten 1991) but the process of interment was not affected by religion. The large vaults had access from either within the church or from the exterior, sometimes well-hidden but in other cases marked by a door or inscribed slabs. Most vaults of this size incorporated ventilation grilles or shafts within their original designs (Litten 1999).

The Roper vault beneath what had been the family's chantry chapel was constructed as an addition to St. Dunstan's parish church, Canterbury, to the south of the chancel (Tatton-Brown 1980). It was constructed in the early $16^{\text {th }}$ century, just decades before the Reformation and the end of such chapels, and it was designed with a niche to contain a lead box containing the head of Sir Thomas More, made a saint within the Roman Catholic church. The burial vault was able to house four interments on the floor of the vault, reached by a set of steps entered from within the chapel, and continued in family use for several centuries (Fig. 3). An awareness that it would fill relatively quickly was acknowledged with the provision at the southern end of a shaft into which human remains and coffin fragments could be placed, and indeed had been used for eight individuals.

Rycote Chapel, Thame, was constructed as a chantry chapel in I 449, though the vault beneath only began to be used for interments from the mid-I $7^{\text {th }}$ century by the then owners of the nearby Rycote House. The vault became filled with 26 coffins, almost all of the Bertie family, which survive neatly laid out, though not all in parallel East-West orientation (Boston 2007). The pattern of filling of the vault is informative, and this discussed later as an example of a larger family vault biography (Fig. 6).

The Shirley vault, Ettington, Warwickshire, was $5.0 \times 3.8 \times 2.2 \mathrm{~m}$ in size and contained four shelves, two at $0.6 \mathrm{~m}$ from the floor and the others at $1.2 \mathrm{~m}$ on each long side. These, and the floor spaces beneath shelves, would have held six coffins, but in fact none had been used and the vault was empty (Collins, McNicol 2008). The use of shelves is a common choice for larger family vaults, normally placed so that their long sides were visible. An alternative, with some larger vaults, is that the coffins were inserted end-on into loculi, which is a way of arranging coffins seen in some community crypts (Litten 1999). The Castle Howard mausoleum was designed with loculi, and here the chambers containing a coffin were sealed with a stone tablet inscribed with the names and dates of the deceased, though many are still unfilled. In most family vaults, they are not sealed off. Some vaults were upgraded over time; this was the case with the Sackville vault, Withyham, Sussex, 


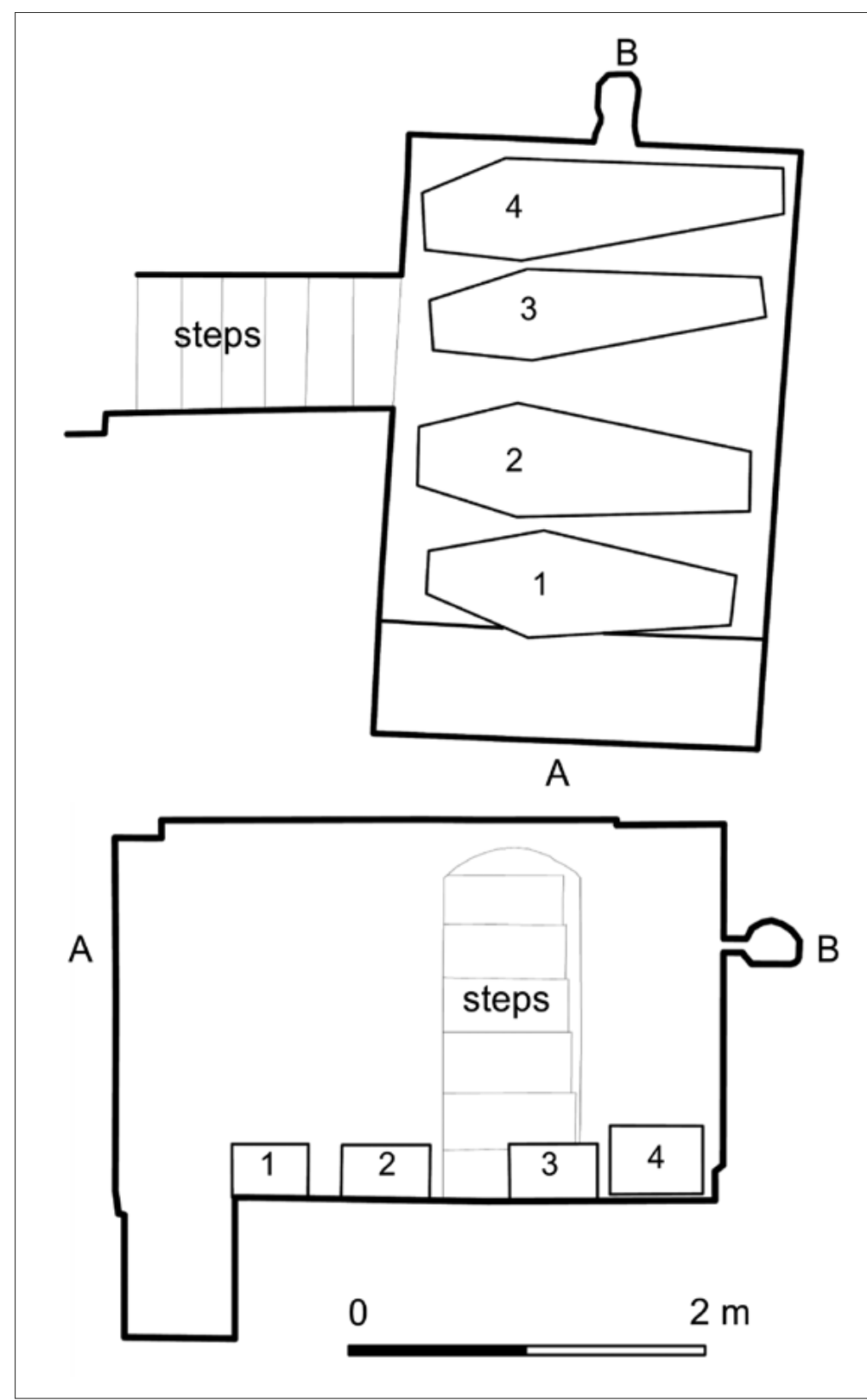

Fig. 3. Roper Chapel vault, St. Dunstan's parish church, Canterbury. Plan and elevation of the vault with a niche, four coffins on the floor, and a sunken location for charnel and coffin fragments (Mytum and Philpott, simplified from Tatton-Brown 1980). 
built in 1677 with coffins to be placed on the floor, but refurbished with shelves and the coffins rearranged in I825 (Litten I999: IIO-III). There was sufficient room with this new arrangement for a mortuary table in the centre of the vault for the latest interment to rest.

\section{Community crypts}

Many parish churches in urban centres were either built with underground spaces for the interment of human remains from their initial design, or had crypts originally used for other purposes converted to this use. These provide large samples of mortuary data as they were often popular with the middle classes able to avoid the overcrowded churchyards with their risks of bodysnatching, inter-cutting graves, and an unseemly final stage in the interment of family remains. Whilst community crypts could have space compartmentalised by additional walls and railings to create family vaults, as at Bloomsbury, most contained spaces which contained members of many different families. Most crypts had stone or brick floors, though St. Luke's had an earth floor allowing earth-dug graves. Some crypts had wooden or iron racks fixed to the walls which allowed the coffins to be stacked in separate shelves, preventing crushing, though many others did not. In these cases, coffins were stacked, with sometimes larger ones at the bottom and smaller (including those of children) at the top. Small spaces and alcoves were also used, often filled with small coffins.

At Bloomsbury, the crypt consisted of a number of distinct areas (vaults I-7) of varying size set to the north and south of a central aisle, accessed by a flight of stairs. Only vault $\mathrm{I}$ had the racking remaining in one part of the vault, and other vaults had evidence on the walls for racking that had been removed. In vault I, most of the coffins were not on the racking, and were just stacked, and that was the case in the other vaults. Some may have been moved when the crypt was closed in 1856 , when the central aisle was cleared of any coffins and the vaults bricked closed (Boston et al. 2009: 36); it is possible that some of the racking was recovered at this time, so some of the stacking of coffins even in the vault where they were originally placed could have been re-ordered. Nevertheless, the stacks reveal an unexpectedly high degree of coffin movement, and this is discussed below as an example of a coffin biography.

\section{Biographies of coffins}

By untangling the biography of things, the importance of different features of the artefact can be identified as significant at certain times, and not at others. This approach identifies the ways in which value and meaning of an artefact changes 
over time, space and social context (Gosden, Marshall 1999), and it can be applied to both artefacts such as the coffin and structures, such as a vault. Being more mobile that a vault or crypt, the coffin's biography is more complex in that it was visible in a variety of different of physical and social contexts, unlike the fixed and subterranean burial spaces. All the biographies, however, reveal new insights into the significance of such material items to those who commissioned and used them.

The coffin in the $18^{\text {th }}$ or $19^{\text {th }}$ century was made to order for a particular deceased individual, though the production process and choice of coffin fittings (also called furniture) rapidly developed in Britain into a commercial arrangement that combined the use of mass-produced elements that were assembled into a bespoke combination for each client (Church, Smith 1966; Mytum 2004; 2018b). Earlier coffins, and some in the ${ }^{8} 8^{\text {th }}$ century in rural areas were still produced by local parttime undertakers for which the funeral business was only part of their income. For wooden coffins they were otherwise carpenters, for lead coffins they were plumbers, used to working with the appropriate materials. Numerically, however, by the mid-I $8^{\text {th }}$-century most burials would have been arranged through a professional undertaker, modelled in some respects on aristocratic funerals, though Litten (199I) emphasises this to the exclusion of the agency of first the middle and later the working classes in affecting the details of the coffin and indeed the whole of the funerary process. Burial societies enabled working classes to have a socially acceptable funeral (Moerman, van der Laan 2020), though these were within expenditure levels that meant that the interments were in earth-cut graves and so beyond the remit of this paper. Coffin quality and finish was dependent on the funds available for the funeral; from the later $\mathrm{I}^{{ }^{\text {th }}}$ century the middle classes had coffins covered with fabric. In the later $19^{\text {th }}$ century the quality of wood and its working became significant again as fabric coverings went out of fashion, but by this time most coffins were made in factories and sent to undertakers who ordered the appropriate size, style and finish, the coffins then distributed by train (Mytum 2015).

The creation of a distinctive popular form of mortuary practice in terms of the coffin and its interment still requires considerable attention to more fully appreciate the forces operating on the products, through archival research and those surviving unused samples and production sites such as the Newman Brothers Coffin Works, Birmingham (Buteux 2017). The conservatism in styles, with limited and slow change compared with contemporary mortuary monuments, suggests that the coffin producers - the undertakers - had a more dominant role than in many other forms of contemporary consumer behaviour and consumption. The bereaved consumers were often not in an emotional state which enabled them to make decisions about the coffin; they generally left this to the professionals who gauged their social position and ability to pay to decide on the appropriate level of ostentation (Mytum 20I5; 20I8b). 
A typical wooden coffin starts life in the undertaker's workshop where it is constructed of materials already in stock. Whilst burials of the destitute from the workhouse may have had coffins constructed from scraps of wood, possibly reused, most coffins had new sawn timber. A range of species were used, and the coffin was fixed together using iron nails. For much of the $\mathrm{I}^{\mathrm{th}^{\mathrm{th}}}$ - and into the $19^{\text {th }}$-century, there may have been several coffins nested one inside the other (in some cases including a lead coffin layer to seal in any liquids and odours that may emanate from the corpse). Many coffins were also covered with fabric, usually wool, which came in a range of colours. The fabric was then held in place with decorative patterns of copper-alloy upholstery pins, and could also have additional tinned iron plates, many with elaborate stamped designs, on the top of the coffin and additional small plates, escutcheons, on the sides. There were also handles, usually held in plate by decorated plates, on the sides of the coffin, though these were decorative and not functional. The depositum plate, with name and other details, was normally on the top of the coffin. The variability of designs in the metalwork, and their arrangement, was first noted at Spitalfields (Reeves, Adams 1993) but is now even more widely appreciated (Death across Oceans... 2018).

Coffin components start as raw materials converted into generic planks in the case of the timber, before being purchased by the undertaker. The coffin fittings in the $17^{\text {th }}$ and early $18^{\text {th }}$ century were items produced primarily for the furniture trade, and had no associative funerary association or meaning, but during the $18^{\text {th }}$ century a repertoire of products was produced specially for coffins, though upholstery pins continued to be standard products. These were largely manufactured in the West Midlands of England where they formed a product amongst many others by those in the 'metal-bashing' industries (Church, Smith 1966). The capitalist foundry owners merely saw this as an extension of their markets into a new area of demand, supplying undertakers with items displaying designs appropriate to their purpose whilst also producing hardware for furniture, and for the construction industry.

Fittings for coffins were individually low-value bulk products in the eyes of the producer, and part of the stock by which to furnish coffin orders with the perspective of the undertaker. The greater the number and the more elaborate the form of the fittings that could be sold with a coffin, the greater opportunity for profit for the undertaker. Most fittings were made of iron stamped out into a repoussé design which was usually tinned for a shiny silvery finish, or they were painted or lacquered to be a funeral black. Use of other materials for fittings - copper alloy or in some cases solid silver - provided additional opportunities for profit. Whilst the undertaker recognised some variation in consumer choice beyond elaboration - notably by religion with crucifixion plaques available for Roman Catholics for example - there is little evidence that the undertakers were greatly concerned about the symbolism and meaning of any designs. 
There is little evidence of interest by undertakers in generating stylistic change. Demand was dictated only by the necessity of a decent funeral, and it could not be expanded by creating fashion trends. This led to a conservative tradition in designs across the sector (Mytum 2018b), in contrast to memorials which show clear fashion trends. However, that does not mean that the coffin and fittings did not have any significance beyond the functional container for a cadaver. Many coffins had name plates affixed to them which served to identify the deceased at all stages of its journey to interment; this could be a simple inscribed or painted plaque or could be an elaborate mass-produced design with a central area on which the text could be added in an appropriate style. This recognised the significance of the individual (Mytum 20r8a). Variability was also achieved though the colour of fabric which could cover the coffin, and the pattern of upholstery pins which held this in place but also created designs on the sides and sometimes the lid of the coffin.

The bereaved wished, as part of a widespread cultural expectation, to have a socially respectable sequence of funerary practices following a death. An early stage of this was the presentation of the body, within its open coffin, within the family home in a room which could be visited by friends, neighbours and relations as part of a pattern of condolence (Jalland 1996). Here, the treatment of the corpse, its presentation including coffin lining and any funeral clothes (though sometimes the deceased was dressed in their own clothes) and the coffin itself would, in combination, be the centre of attention. This was the only moment in the coffin's life when the whole coffin design, and the detail of the form and decoration of the fittings, could be inspected by a socially significant audience. This period of semi-public agency lasted only a few days, and that is why the products could have a smart appearance but did not have to be manufactured for any other functional effectiveness or longevity. Funerary clothing did not have hems as the cloth did not have the opportunity to unravel, and it was not sewn together at the back as the wearer was not going to move from their prone position (Janaway 1993; 1998). For the cadaver to look (and indeed smell) its best, the body could be set on sawdust, and sprigs of plants could also be added to the coffin contents; jewellery and false teeth could remain with the body (Cherryson 2018).

The period of mourning with the deceased present in the house was important for the spread of normative practice within any social group. Those arranging a funeral would have already attended many such events and have called upon numerous bereaved families and inspected their coffins, noting their choice of fabric colour, arrangement of upholstery pins and the nature of the remaining fittings. This would have been particularly the case when visiting families where there was less emotional attachment, so that the observations of the material accoutrements could be absorbed without being swamped by the emotion of the occasion. As coffins only remained in this visible sphere before a short public journey (when 
more people could see the coffin, but only fleetingly) to the place of the funeral service, and then being interred, all the efforts in agreeing and producing the design were only appreciated at this point. These few days were when the coffin's agency was at its height.

The public display of the coffin whilst transported to the funeral service would vary - either carried on shoulders of the bearers, on an open hearse moved by a person or a horse or within a closed, glass-sided hearse with a pair or more of horses. Only on the open hearse might the top of the coffin be visible on this journey, and then briefly. During the service in church or chapel, and at interment, opportunities for detailed observation were no better. The coffin (and what it contained) may have been the focus of attention, but the life and character of the deceased were the aspects most of the congregation were absorbing and reflecting upon. The coffin was at this stage publicly visible and provided generalised messages regarding the quality and extent of elaboration that would have fed into the assessment of the seemliness (or otherwise) of the occasion by the congregation. Too ostentatious a display, or an apparent frugality, would be identified against the observers' expectations from their previous funeral and family visit experiences. The agency of the coffin in the creation of new or the reinforcement of existing social positions for the deceased was high; the ensemble indeed reflected at least as heavily on the bereaved who had made the choices (or at least acquiesced to undertaker's suggestions) regarding the coffin and its fittings. These social perceptions would be highly contextualised; the same coffin could be viewed differently by diverse audiences with their own expectations. It is notable that coffins for Quakers, who were not allowed elaborate memorials over their graves, could be as ostentatious as for other denominations (Stock 1993).

The disposal of the coffin and the body it contained would then be in an earth-dug grave or into one of the spaces described above, the shaft giving a similar experience at interment as that of an earth grave where the mourners leave for the coffin to be covered by earth by the gravediggers. The others provided a different perspective, with the coffin being taken either down steps into a family of communal vault, or it was pushed into a smaller aperture that provided access for the coffins. Once out of sight, only those moving the coffin knew what happened to the container and its contents. In Britain, smaller family vaults or community crypts were not accessible to relatives. Those external subterranean structures with above-ground markers could still act as the foci for visiting and remembrance, but this did not entail any direct access to the coffin. Whilst St. Michan's church, Dublin, has had crypt tours for over 80 years where the coffins (and indeed some mummified human remains) are visible (Hobson 1935), this is nevertheless a more recent tourist dimension to visiting, rather than a tradition from the time the interments were made. 


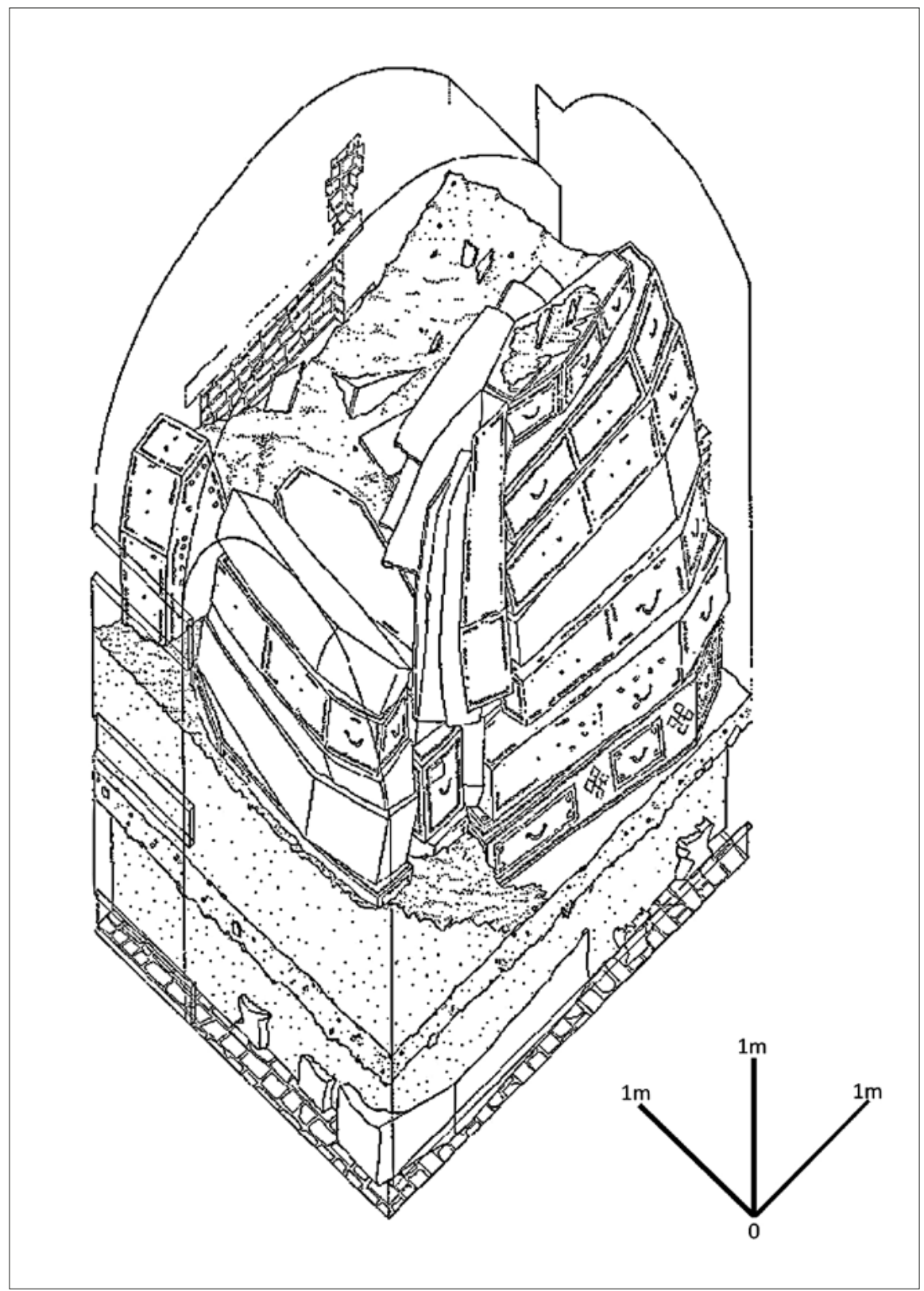

Fig. 4. Isometric drawing of the northern parochial vault within the communal crypt at Christ Church, Spitalfields, London, showing the stacking and placement of coffins vertically (Reeve, Adams 1993; research funded by English Heritage and derived from the Archaeology Data Service). 
In smaller vaults and shafts, the biography of coffins follows a simple one of decay and collapse, possibly leading to complete rotting of textiles and wood, and severe corrosion of the fittings. This is common where conditions are damp. In some cases, drier conditions allow the coffin to remain intact, with its cloth covering and the fittings having only a small amount of tarnishing. The state of preservation within the container varies greatly and does not seem to have any direct relationship to that which is visible; the taphonomy of human remains, textiles and other materials within the coffin is still a subject of active research (Lipkin et al. 2020).

Many coffins do not rest in peace, however, being moved about within the space within which they were placed, especially in community vaults. More recent coffins were stacked on older ones can lead to the lower ones being crushed, so they were often moved to one side to create a space for the new insertion into the vault. The extent of this phenomenon was first revealed at Spitalfields where every available space was used, with coffins stacked up to the roof of many of the parts of the crypt (Fig. 4).

The numerous interments at Bloomsbury were arranged in rows and stacks, carefully recorded by Boston et al. (2009) who point out the extensive evidence for movement of coffins. Some coffins were arranged in racking, but others were just piled one on another (as was the case at Spitalfields). Two of the non-rack rows of stacks in vault I illustrate the chronological mixing (Fig. 5). The central stack of row I shows the expected pattern of deposition with the oldest coffin at the bottom and the latest at the top, with the rest in sequence in between. However, the other four stacks in Row A and all those in row D reveal more mixed sequences, demonstrating the amount of movement. This could include the placing of family members together (four of the Burley and two of the Groom families - shown shaded) but that does not fully explain the order. In row D, only two adjacent stacks contained members of the Hay family set next to each other, and the rest of the arrangement appears random. Not all the re-ordering can be explained by any movement of coffins when the vaults were closed; this must have been a frequent shuffling to keep maximising the space use within these constrained locations.

Sometimes, the burial space is reorganised, and at Spitalfields this led to the splitting up of family groupings, packing as many coffins as possible into chambers, and in standing coffins on end to create space for more (Reeve, Adams 1993). The overcrowding in this parish crypt was more dramatic than in a family vault, but it indicates how in all cases those entering these spaces were considering the immediate problem to be solved - introducing an additional coffin - over respect and appreciation of those coffins already present. As none of the actions were visible to the family or wider community, this hidden, secret pattern of behaviours reveals that the coffins now had no social or symbolic significance. There was a widespread 
attitude from those with the responsibility of continuing interment traditions in such spaces that the desire to see the coffin of the newly-deceased enter this space was the overriding concern. Its hidden consequences were of no account.

The coffin's visible, socially significant, biography was a matter of days - first at the home of the deceased where a limited number but to the bereaved most socially significant observers could examine the choices in detail, followed by only hours of more public viewing before descending from sight for ever. For earth-dug graves the coffin was then permanently beyond view, and although coffins in crypts and vaults may remain visible within those spaces, the audience was thereafter tiny. It was possible that families could visit vaults within crypts beneath churches (or Vault Io in St. Martin's-in-the-Bull Ring churchyard) but there were no decayed flowers or wreaths found to suggest this occurred. Instead,

Vault 1 Row A

\begin{tabular}{|c|c|c|c|c|}
\hline 1840 & nd & 1846 & sand & sand \\
\hline 1845 & 1826 & 1837 & 1838 & 1818 \\
\hline 1820 & 1831 & 1836 & 1847 & nd \\
\hline 1837 & nd & 1823 & 1827 & 1837 \\
\hline 1824 & 1826 & 1810 & 1813 & 1831 \\
\hline 1826 & 1839 & 1808 & 1830 & 1832 \\
\hline
\end{tabular}

\begin{tabular}{|c|c|c|c|c|}
\hline 5 & nd & 6 & sand & sand \\
\hline 6 & $1=$ & 5 & 4 & 1 \\
\hline 1 & 3 & 4 & 5 & nd \\
\hline 4 & nd & 3 & 2 & 4 \\
\hline 2 & $1=$ & 2 & 1 & 2 \\
\hline 3 & 4 & 1 & 3 & 3 \\
\hline
\end{tabular}

Vault 1 Row D

\begin{tabular}{|c|c|c|c|c|}
\hline 1833 & sand & sand & 1813 & 1835 \\
\hline 1828 & 1826 & 1839 & 1830 & 1835 \\
\hline 1820 & 1837 & $\mathrm{nd}$ & 1847 & 1840 \\
\hline $\mathrm{nd}$ & 1840 & $\mathrm{nd}$ & 1839 & 1835 \\
\hline 1843 & 1806 & 1829 & 1810 & 1832 \\
\hline 1814 & 1830 & 1848 & $\mathrm{nd}$ & 1817 \\
\hline 1820 & 1832 & 1820 & 1831 & sand \\
\hline
\end{tabular}

\begin{tabular}{|c|c|c|c|c|}
\hline 5 & sand & sand & 1 & $3=$ \\
\hline 4 & 2 & 3 & $3=$ & $3=$ \\
\hline $2=$ & 5 & nd & 5 & 6 \\
\hline nd & 6 & nd & 4 & $3=$ \\
\hline 6 & 1 & 2 & 2 & 2 \\
\hline 1 & 3 & 4 & nd & 1 \\
\hline $2=$ & 4 & 1 & $3=$ & sand \\
\hline
\end{tabular}

Fig. 5. Diagrammatic representation of Rows A and D in Vault I at St George's Church, Bloomsbury. Some family groupings are shaded: Row A four Burley members (green), two Groom members (blue); Row D two Hay members (brown) (Mytum and Philpott, created from data in Boyle et al. 2005). 
only those concerned with the addition of further coffins would enter these spaces, not obtaining meaning from those already there but concentrating on placing the addition within the space. The pattern of public crypt visiting seen in some European countries such as Finland and Italy (Väre et al. 2020; Stone 2006) was never a feature of British burial ground visiting. Indeed, public catacombs as at some of the larger cemeteries such as Brompton Road and Highgate in London and St. James', Liverpool, remain largely unfilled to this day even though they may form architecturally significant features in the cemetery landscape (Curl 1980). Even family mausolea, such as that at Castle Howard, North Yorkshire, contain many empty loculi, as members of the family have not always wished to be interred at that location (Mytum 2007).

If left undisturbed, coffins with their fittings and coverings could remain remarkably intact and well preserved, but a damp atmosphere often led to outer layers (shells) of multicomponent coffins and their coverings often decayed away, revealing an inner lead component which then often corroded to a whitish colour. All-wood coffins could completely disintegrate, leaving the human remains surrounded by a scatter of metal fittings. Disturbance by animals may sometimes occur, though most vaults were well-constructed with mortared bricks which impeded rodent access. More problematic could be intermittent rising levels of groundwater, which could lead to coffins moving around in the water and settling in new locations as the water levels fell.

\section{Crypts and vault biographies}

Crypt and vault biographies are intimately linked to those of the coffins, with the number and relative frequency of interments affecting how they could be accommodated. The small vaults have limited biographies as they often only contain one or two interments, the latter usually husband and wife. The vaults at St. Martins with several levels demonstrate more complex filling as shown with the Ashworth vault discussed above (Fig. I), a pattern also seen with the Jenkins vault though most, such as the Warden and Haines vaults, were filled in chronological order, starting at the lowest level (Brickley, Buteux 2006: 39-70).

The vaults within crypts also largely had short and limited use (Tab. I), or sometimes even no use at all (e.g. St. Luke's vault 104). The average use life where this can be estimated at St. Luke's was is years, but this varied from just one occasion ( 5 cases) to up to 77 years (vault 126). At St. Martins the average was greater at 42 years, with a maximum of 73 years. Those vaults with longer activity sometimes with a late phase of extreme overcrowding; the fullest vault at St. Luke's contained II interments, but this was a much larger vault than the others at this church; the most at St. Martins was I3. 
Tab. 1. Chronology of burial vault forms (after Litten 1985: I0, with additions based on recent discoveries).

\begin{tabular}{|l|l|}
\hline LATE $16^{\text {th }}$ CENTURY & Vertical walls on all sides and gently curving roof \\
\hline EARLY $17^{\text {th }}$ CENTURY & Vertical walls on all sides and flat roof \\
\hline MID TO LATE $17^{\text {th }}$ CENTURY & Vertical walls on all sides and slightly barrelled roof \\
\hline $18^{\text {th }}$ CENTURY & $\begin{array}{l}\text { Vertical E and W walls and barrel vault springing from } \\
\text { low on the N and S walls }\end{array}$ \\
\hline $19^{\text {th }}$ CENTURY & $\begin{array}{l}\text { Vertical walls on all sides and flat roof (many examples } \\
\text { of } 18^{\text {th }} \text { century design continue to be built) }\end{array}$ \\
\hline
\end{tabular}

The numbers of interments and the time over which they took place creates an activity rate for each vault - an average of an interment every five years at St. Martins, this is more difficult to calculate for St. Luke's as many vaults only had few dated interments, but the average seems to be only slightly greater. With low density use, coffins could be arranged on the floor, raised on beams, or placed on specially constructed shelves or loculi. As intensity of interment increased, older coffins were moved out of the way, sometimes disintegrating in the process, or new coffins were stacked on top of the existing occupants, causing the collapse of those below. Access was via steps leading to a door normally bricked up or sealed with a stone slab, or via a removable slab in the roof (in at least two cases, the slabs were re-used gravestones); in both arrangements, the intermittent disturbance could be fully repaired, and vaults only seem to have received alteration if accidentally discovered during later construction works when the location of the vault had been forgotten. In these cases, the vaults could be left as voids but re-sealed, used for charnel created by the building work, or filled with sand to help stabilise the building.

Elite family vaults could have longer biographies, and Rycote Chapel vault (Boston 2007) is an excellent example of this pattern (Fig. 6). The earliest interments were two infants $(\mathrm{I}, 2)$, in the north-eastern corner; they are probably undisturbed (though are both unusually with their heads to the east) as the next interment (3), the I ${ }^{\text {st }}$ Earl of Abingdon, was then placed in the south-eastern corner. The first $18^{\text {th }}$-century interment (4) is the brother of one of the infants (2) and was placed next to him. The remaining early $18^{\text {th }}$-century interments are grouped in the south-eastern corner, the $2^{\text {nd }}$ Earl's wife (6), followed by her husband (7), with the $3^{\text {rd }} \operatorname{Earl}(8)$ and then his wife $(7)$ next to be interred. In the later $18^{\text {th }}$ century, an unmarried daughter of the $3^{\text {rd }} \operatorname{Earl}(9)$ and the $3^{\text {rd }}$ Earl (Io) himself were added, 


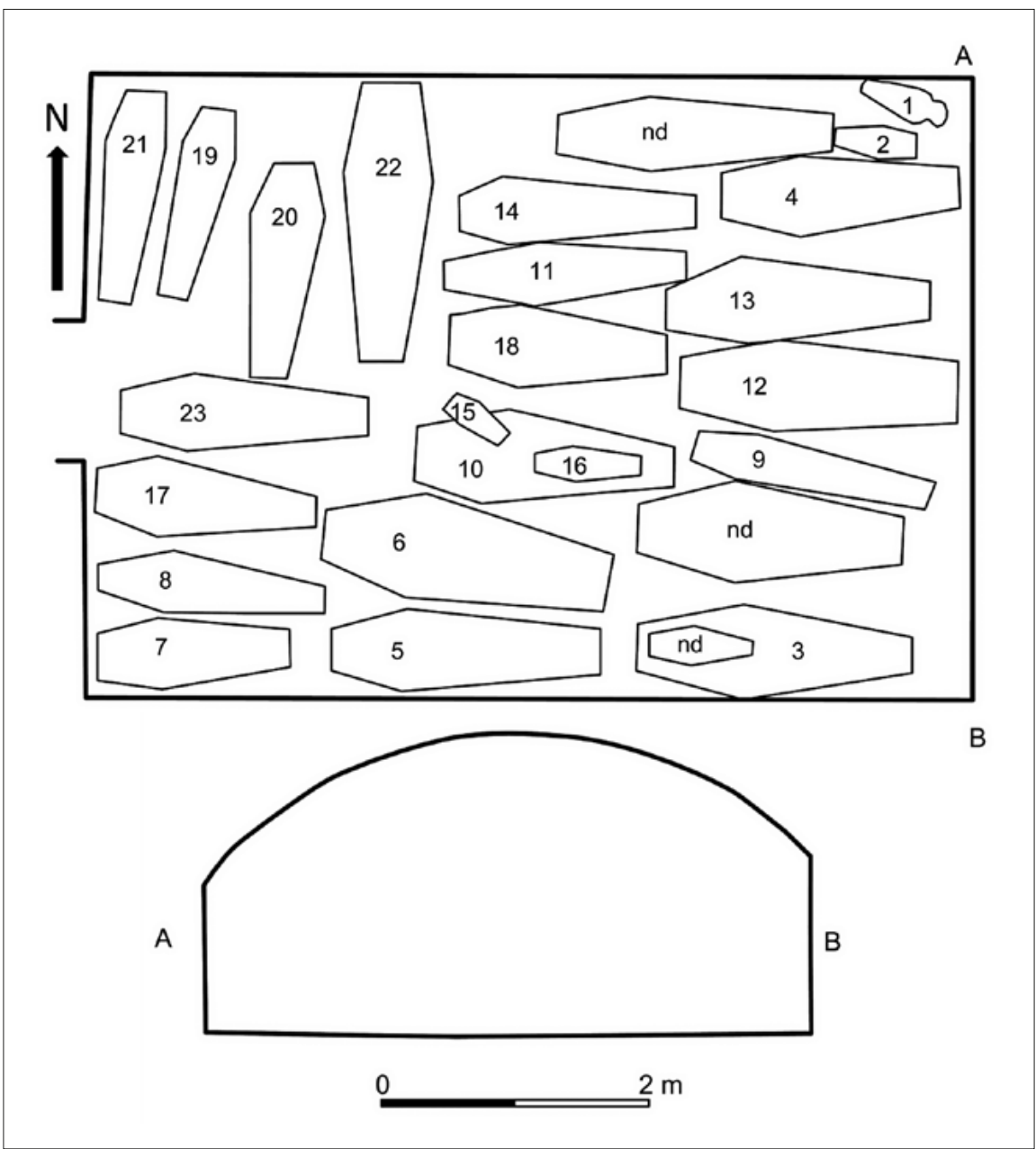

Fig. 6. Plan of family vault containing members of the Bertie family, Rycote Chapel, Thame, numbered in order of interment (Mytum and Philpott, created from data in Boston 2007).

followed by his wife (II), the $4^{\text {th }}$ Earl's wife (I2) and the Earl (I3) and his unmarried daughter (I4). Two infants (I5, I6) were then placed on top of the $3^{\text {rd }}$ Earl's coffin (9) and, as the remaining space became more restricted, the next coffin (17) was placed just south of the entrance and the one remaining space in central part of the floor was used (18). Attention then turned to the north-western area, with four coffins (19-22) placed in a north-south orientation, including the $5^{\text {th }}$ Earl and his wife $(20,22)$. The final burial was laid just at the foot of the steps, completely filling the vault; this was the ${ }^{{ }^{\text {th }}}$ Earl, completing almost 250 years of the crypt biography. 
Parish crypts have their own biographies which, given the number of burials and the greater number of individuals involved in their management over a longer period of time, have more complex histories. Though most happened out of sight of the bereaved and the Sunday congregations, and it is likely many of the details were also unknown even to the vicar and churchwardens. The private vaults within the St. Luke's crypt were not part of the original design, but they were constructed in a variety of different styles and butt-jointed to the crypt walls (Boyle et al. 2005). Their gradual arrival (in Bay 2 from 1814 to 1846 and Bay 3 from 1800 to 1845 ) altered the internal geography of the crypt and limited the space for earth-dug graves. It shows a privatisation of the burial space in the same way as monuments and plots with railings were used in the graveyard.

\section{Conclusions}

The evidence for subsurface structures in Britain, and particularly England, has increased greatly since Julian Litten's seminal classification in 1985 . Moreover, the geographical spread of investigated structures has also reinforced the widespread provision of built subterranean burial spaces and that, whilst there are regional and local variations, there is a clear set of sizes of such spaces, and a limited range of management principles applied to them. Whilst individual biographies vary as such structures were adapted and filled, many valid generalisations about typical use lives can now be made for the first time, and the ways in which the coffin passed on its journey during body disposal and mourning to reside and in many cases decay within its built structure can be set out and its varied agency considered.

As the shafts, vaults and crypts were the popular choice of burial location for the more affluent portions of the middle classes and of the aristocracy, they provide an important material representation of those groups' concerns over the bodies of the deceased. Despite their invisible character, they were considerable investments that do not relate to overt display (though monuments above them may do so). Rather, they indicate concerns over the body, and the type of company with which the bereaved wished their relatives to await the Second Coming. A fuller exploration of the meanings of such spaces is still required, but this can only be achieved once the degree of variation in such data, and how it relates to familial relations across generations, is assessed. This study reveals the recent increase in data and understanding of mortuary practices since Litten's pioneering $20^{\text {th }}$-century works. The mitigation in advance of church and churchyard alterations - large and small - are all accumulating valuable data for analysis beyond that of individual, site-specific case studies, and revealing larger scale patterns in Britain and Ireland. 
Note: For consistency, all measurements within this study have been presented to the nearest $0.1 \mathrm{~m}$. The 'grey literature' reports have used a variety of terms for vaults and crypts, but here the various burial chambers have been described using the terminology set out at the start of the chapter. Many of the line illustrations were drawn by R. Philpott and annotated by the author.

\section{Bibliography}

Boore J.J. (1986), The Church of St Augustine the Less, Bristol: an Interim Statement,

"Transactions of the Bristol and Gloucestershire Archaeological Society", I04, p. 2II-2I4.

Boston C. (2007), Rycote Chapel Coffins in the Crypt, Thame, Oxfordshire (unpublished archaeological watching brief report, Oxford Archaeology, Oxford).

Boston C., Boyle A., Gill J., Witkin A. (2009), "In the Vaults beneath". Archaeological Recording at St George's Church, Bloomsbury, Oxford Archaeology, Oxford (Oxford Archaeology Monograph, 8).

Boyle A., Boston C., Witkin A. (2005), The Archaeological Experience at St Luke's Church, Old Street, Islington, Oxford Archaeology, Oxford.

Brickley M., Buteux S. (2006), St. Martin's Uncovered. Investigations in the Churchyard of St. Martin's-in-the-Bull Ring, Birmingham, 200I, Oxbow Books Limited, Oxford.

Buteux S. (2017), A 'Mercantile Marie Celeste': The Newman Brothers Coffin Furniture Works in Brirmingham's Jewellery Quarter, "The Archaeologist", 89, p. 46-53.

Butler L.A.S., Morris R. (1994), Derby Cathedral: The Cavendish Vault, "Derbyshire Archaeological Journal", i16, p. I4-28.

Cherryson A. (2018), Dressing for the Grave: The Archaeological Evidence for the Preparation an Presentation of the Corpse in Post-Medieval England, [in:] H. Mytum, L.E. Burgess (ed.), Death across Oceans. Archaeology of Coffins and Vaults in Britain, America and Australia, Smithsonian Institution Scholarly Press, Washington DC, p. 37-55.

Cherryson A., Crossland Z., Tarlow S. (2012), A Fine and Private Place. The Archaeology of Death and Burial in Post-Medieval Britain and Ireland, University of Leicester, Leicester (Leicester Archaeology Monograph, 22).

Church R.A., Smith B.M.D. (1966), Competition and Monopoly in the Coffin Furniture Industry, I870-I9I5, "Economic History Review", 19, p. 612-641.

Collins P., McNicol D. (2008), St. Thomas á Becket House, Ettington, Warwickshire. Archaeological Evaluation and Watching Brief. Final Report (unpublished archaeological report Birmingham Archaeology, Birmingham).

Cox M., Stock, G. (1996), Nineteenth Century Bath-stone Walled Graves at St Nicholas' Church, Bathampton, "Somerset Archaeology and Natural History", I38, p. I3I-I5O.

Curl J.S. (1980), A Celebration of Death. An Introduction to Some of the Buildings, Monuments, and Settings of Funerary Architecture in the Western European Tradition, B.T. Batsford, London. 
Dean B., Hiller J. (2007), St John's College Chapel, St. Giles, Oxford (unpublished archaeological watching brief report, Oxford Archaeology, Oxford).

Death across Oceans. Archaeology of Coffins and Vaults in Britain, America and Australia, Smithsonian Institution Scholarly Press, Washington DC.

Gosden C., Marshall Y. (I999), The Cultural Biography of Objects, "World Archaeology", 3I (2), p. I69-I78, https://doi.org/I0.I080/00438243.1999.9980439

Hobson G.D. (1935), The Church with the Crypts, "The Irish Monthly", 63 (745), p. $452-456$.

Jalland P. (1996), Death in the Victorian Family, Oxford University Press, Oxford, https://doi.org/Io.I093/acprof:oso/9780198201885.00I.000I

Janaway R. (1993), The Textiles, [in:] J. Reeve, A. Adams, The Spitalfields Project, vol. I, The Archaeology. Across the Styx, Council for British Archaeology, York (Research Report, 85), p. 92-II9.

Janaway R. (1998), An Introductory Guide to Textiles from $18^{\text {th }}$ and $19^{\text {th }}$ Century Curials, [in:] M. Cox (ed.), Grave Concerns. Death and Burial in England I700 to I850, Council for British Archaeology, York (СвA Research Report, I13), p. I7-32.

Langthorne J. (2006), An Archaeological Watching Brief at Boone's Chapel, Lee High Road, London Borough of Lewisham (unpublished archaeological watching brief report, Pre-Construct Archaeology Ltd., London).

Lewis J. (2009), The Parish Church of St Nicholas, Cuddington, Buckinghamshire. An Archaeological Watching Brief (unpublished report, Thames Valley Archaeological Services Ltd., Reading).

Lipkin S., Ruhl E., Vajanto K., Tranberg A., Suomela J. (2020), Textiles - Decay and Preservation in the $17^{\text {th }}-19^{\text {th }}$ century Burials in Northern Finland, "Historical Archaeology", 54 (forthcoming).

Litten J. (1985), Post-Medieval Burial Vaults: Their Construction and Contents, "Bulletin of the сва Churches Committee", 23, p. 9-17.

Litten J. (1991), The English Way of Death, Robert Hale, London.

Litten J. (1999), Tombs Fit for Kings: Some Burial Vaults of the English Aristocracy and Landed Gentry of the Period I650-1850, "Church Monuments", I4, p. I04-I28.

Litten J. (2009), The Anthropoid Coffin in England, "English Heritage Historical Review", 4 (I), p. 72-83, https://doi.org/IO.II79/175201609799838474

Moerman L., van der Laan S. (2020), Paupers, Burial Clubs and Funeral Insurance: Calculating Moral Panics, "The British Accounting Review” (forthcoming), https://doi.org/Io.IOI6/j.bar.2020.I009II

Mytum H. (1988), A Newly Discovered Burial Vault in North Dalton Church, North Humberside, "Post-Medieval Archaeology", 22 (I), p. I83-187, https://doi.org/IO.II79/pma.I988.006

Mytum H. (2004), Mortuary Monuments and Burial Grounds of the Historic Period, Springer, New York, https://doi.org/Io.1007/978-I-4419-9038-9

Mytum H. (2007), Monuments and Memory in the Estate Landscape: Castle Howard and Sledmere, [in:] J. Finch, K. Giles (ed.), Estate Landscapes. Design, Improvement and Power in the Post-Medieval Landscape, Boydell \& Brewer, Woodbridge (Society for Post-Medieval Archaeology Monograph, 4), p. I49-I74. 
Mytum H. (2012), In memoriam: Markers, Monuments and Headstones, [in:] M. Connolly (ed.), The Unquiet Grave. The Development of Kerry's Burial Grounds through the Ages, Kerry County Council, Tralee, p. 2-26.

Mytum H. (2015), Artifacts of Mortuary Practice: Industrialization, Choice, and the Individual, [in:] A. Brooks (ed.), The Importance of British Material Culture to Historical Archaeologies of the Nineteenth Century, University of Nebraska Press, Lincoln, p. 274-304, https://doi.org/I0.2307/j.cttId98bqt.I4

Mytum H. (20I7), Mortuary Culture, [in:] C. Richardson, T. Hamling, D. Gaimster (ed.), The Routledge Handbook of Material Culture in Early Modern Europe, Routledge, London, p. 154-167.

Mytum H. (2018a), United in Death? A Comparative Introduction to Historic Mortuary Culture, [in:] H. Mytum, L.E. Burgess (ed.), Death across Oceans. Archaeology of Coffins and Vaults in Britain, America and Australia, Smithsonian Institution Scholarly Press, Washington DC, p. I-I9.

Mytum H. (2018b), Explaining Stylistic Change in Mortuary Material Culture: The Dynamic of Power Relations between the Bereaved and the Undertaker, [in:] H. Mytum, L.E. Burgess (ed.), Death across Oceans. Archaeology of Coffins and Vaults in Britain, America and Australia, Smithsonian Institution Scholarly Press, Washington DC, p. 75-93.

Redknap M. (1985), Little Ilford, St Mary the Virgin, 1984, "The London Archaeologist", 5 (2), p. 3I-37.

Reeve J., Adams A. (1993), The Spitalfields Project, vol. I, The Archaeology. Across the Styx, Council for British Archaeology, York (Research Report, 85).

Renshaw L., Powers N. (2016), The Archaeology of Post-medieval Death and Burial, "Post-Medieval Archaeology", 50 (I), p. I59-I77, https://doi.org/I0.I080/00794236.2016.II6949I

Stanley A.P. (1869), Historical Memorials of Westminster Abbey, $2^{\text {nd }}$ ed. (I ${ }^{\text {st }}$ ed. 1868).

Stock G. (1993), The $18^{\text {th }}$ and $19^{\text {th }}$ Century Quaker Burial Ground at Bathford, Bath and North-East Somerset, [in:] M. Cox (ed.), Grave Concerns. Death and Burial in England I700 to I850, Council for British Archaeology, York (свA Research Report, II3), p. I44-153.

Stone P.R. (2006), A Dark Tourism Spectrum: towards a Typology of Death and Macabre Related Tourist Sites, Attractions and Exhibitions, "Turizam: međunarodni znanstveno-stručni časopis", 54 (2), p. I45-160.

Tatton-Brown T. (1980), The Roper Chantry in St.Dunstan's Church, Canterbury, "Antiquaries Journal”, 60 (2), p. 227-246, https://doi.org/IO.IOI7/Sooo35815000364I6

Väre T., Lipkin T., Suomela J., Vajanto K. (2020), Nikolaus Rungius: Lifestyle and Status of an Early Seventeenth-Century Northern Finnish Vicar, "Historical Archaeology", 54 (forthcoming), https://doi.org/I0.1007/s41636-020-00268-y

Williams P. (2007), An Archaeological Recording at All Saints' Church, Bisley, Gloucestershire (unpublished archaeological watching brief report, Mercian Archaeology).

Wroe-Brown R. (20II), Postman's Park (Path repair) Aldersgate Street London ECI (unpublished archaeological watching brief report, Museum of London Archaeology, London). 


\section{Summary}

\section{Burial Crypts and Vaults in Britain and Ireland: a Biographical Approach}

The range of post-medieval burial structures found in Britain and Ireland defined by Julian Litten in 1985 are reviewed in the light of more recent discoveries. The degree of variability within each of these - lined burial shafts, small family vaults, large family vaults, and communal crypts - can now be evaluated. Using the biography of objects approach for the first time on mortuary data, the changing agency of coffins over their use-lives is considered, with varying degree of visibility during the stages between construction and final deposition. The biography of vaults is indicated through a selection of burial structures, revealing patterns of use over time. Issues of space management, in some cases with considerable overcrowding and movement of coffins, is seen to be problem only with communal crypts. Shafts and vaults were predominantly for few generations, apart from some elite family where the same space could be used over several centuries.

Keywords: biography, Britain, burial shaft, coffins, crypt, vault

\section{Streszczenie}

\section{Krypty grobowe i podziemia w Wielkiej Brytanii i Irlandii: podejście biograficzne}

Szereg pośredniowiecznych struktur pogrzebowych z terenu Wielkiej Brytanii i Irlandii zdefiniowanych przez Juliana Littena w 1985 r. zostaje poddanych rewizji w świetle późniejszych odkryć. Obecnie można określić stopień różnorodności w ramach każdej z grup: grobów szybowych, niewielkich krypt rodzinnych, dużych krypt rodzinnych oraz krypt wspólnych. Wykorzystując po raz pierwszy podejście oparte na biografii przedmiotów w odniesieniu do danych grobowych, rozważana jest zmieniająca się funkcja trumien przez cały ich okres użytkowy, wraz ze zmieniającym się stopniem widoczności między okresami od powstania do ostatecznego zdeponowania w ziemi. Biografia krypt analizowana jest w oparciu o wybrane struktury grobowe, co pozwala odkryć wzorce użytkowania w czasie. Kwestie gospodarowania przestrzenią, co w niektórych przypadkach obejmuje znaczne przeludnienie i konieczność przenoszenia trumien, zdają się być problemem dotykającym wyłącznie krypty wspólne. Szyby i krypty zasadniczo przeznaczone były dla kilku pokoleń, z wyjątkiem kilku elitarnych rodzin, w przypadku których ta sama przestrzeń mogła być wykorzystywana przez kilka wieków.

Słowa kluczowe: biografia, Wielka Brytania, groby szybowe, trumny, krypta, podziemia

\section{Harold Mytum}

University of Liverpool

Department of Archaeology Classics and Egyptology

United Kingdom

e-mail: hmytum@liverpool.ac.uk 